\title{
The Creation of Selves as a Social Practice and Cognitive Process: A Study of the Construction of Selves in Medieval Graffiti
}

\begin{abstract}
My aim with this article is to propose a model for studying the self in graffiti inscriptions, in particular runic graffiti inscriptions from medieval Scandinavia. I combine insights from cognitive and practice theory, and the combination can aid in systematizing the relation between carver, inscription, and context. A premise for the article is that graffiti expressions, and particularly expressions of self, are constructed individually and in relation to others: they are both personal and social. As a basis for the discussions, I draw on examples of graffiti from the Nidaros Cathedral in Trondheim and Maeshowe, Orkney. The two contexts, a cathedral and a grave mound, are widely different, and I demonstrate how the carvers interact cognitively with their material and social surroundings to create inscriptions and expressions of self, fit for each context.
\end{abstract}

Keywords: practice theory, cognitive theory, blending, situated cognition, distributed cognition, agency, runes, graffiti, Maeshowe, Orkney, Nidaros Cathedral, Trondheim, Norway

Medieval graffiti provides a rare insight into the medieval mind. In contrast to manuscript texts, it is not mediated to us by one or more scribes; the medieval texts we can read on walls today are the same texts as those carved and read by people living in the Middle Ages. ${ }^{1}$ Moreover, graffiti inscriptions were created in informal medieval contexts that we rarely have access to today. As such, this material gives us a unique opportunity to study the medieval self.

According to Michael Barnes, "[r] unological theory can only come from the application to specific runological problems of theories from other disciplines" $(2013,27)$. This statement is based on a rather narrow understanding of runology

1 The material carries with it a range of other methodological problems, however, but this is not the place to discuss them.

Karen Langsholt Holmqvist, Norwegian Institute for Cultural Heritage Research and Department of Linguistics and Scandinavian Studies, University of Oslo. 
as a field, but however you define the field, there is general agreement that it lies at a crossing point between several academic disciplines. ${ }^{2}$ Traditionally, these have mainly been linguistics, philology, and archaeology, and though these disciplines are still central to runology, several scholars have explored other approaches to runology in recent years. ${ }^{3}$ Here, I will turn to the social and cognitive sciences for a theoretical foundation. These fields have rarely been used in runology previously, and they have never before been combined in a runological study. They could provide valuable insights into runology, however, as both situated cognition and practice theory emphasize the importance of context. Inscriptions are always closely tied to a context, and the two theoretical disciplines may therefore help the scholar in systematizing the relation between inscription and context. Conceptualizing graffiti carving as a practice may aid our understanding of the interplay between carver, physical surroundings, material artifacts, other people in the carver's surroundings, and the carver's licit knowledge and understanding. Understanding graffiti carving as both a practice and the result of cognitive processes shows the dynamics of the carving process and how it is upheld and how it evolved over time through each carver's cognitive engagement and participation.

In this article, I will discuss and merge two theoretical approaches that can be used to access the self in medieval graffiti inscriptions ${ }^{4}$ : cognitive theory,

2 See, for example, Terje Spurkland (1987), who argues that runology should include linguistics, philology, archaeology, and cultural history, but that the primary focus should be on the first two. Lena Peterson (1995) presents both a narrow and a broader definition but concludes that "[k]ärnan i runologin måste alltid vara språkvetenskaplig" (the core of runology must always be linguistic [my translation]) (ibid., 41). Michael Lerche Nielsen (1997) agrees, in the main, with Spurkland and Peterson, but he places a stronger emphasis on archaeology as most new finds appear in archaeological excavations, and he places runology between linguistics and archaeology.

3 See, for instance, Henrik Williams' (2013) exploration of the social dimensions of runestones, Judith Jesch's (1994) discussion of pitfalls and opportunities of using runic inscriptions in the study of social history, Marco Bianchi's (2010) multimodal and semiotic analysis of the Swedish runestones, and the various contributions on epigraphy and intermediality in Bauer, Kleivane, and Spurkland (2018).

4 Graffiti inscriptions are particularly apt for illustrating how we can study the self, as we may assume that there is generally only one agent per inscription: the carver. In formal inscriptions, for instance, the matter is often complicated by a number of unknown agents, such as donors and commissioners. Therefore, the reader should be aware that what is presented here is a simple model, aimed at "graffiti selves." Studying the self in other types of inscriptions will often require the addition of complicating factors. However, I start with a simple model to single out the most basic factors. Only then can one proceed to more complicated matters. 
particularly the concept of situated cognition, and practice theory as it is presented by Theodore Schatzki and Andreas Reckwitz. ${ }^{5}$ The merging of these two theories results in two premises for my discussions. The first is that graffiti inscriptions are essentially a product of both practices and cognition. Second, the self emerges through the carving process and is a cognitive construction that is constantly shaped and reshaped in relation to the social and material environment. In the discussions, I will explore two research questions: 1) how is the interplay between practice and cognition visible in the inscriptions?, and 2) how are the selves expressed in the inscriptions shaped by the carvers' cognition and the practice of carving? As a basis for discussing the research questions, I will use examples from two widely different locations where much medieval graffiti has been found: the Nidaros Cathedral and Maeshowe. Approaching a varied material with the combination of these two theories will illustrate the relevance and usefulness of combining the two theories when studying various inscription-contexts. I argue that merging practice theory and cognitive theory can give us an understanding of inscriptions as cognitive products created through a practice and of the self as both a cognitive and social construction.

\section{Merging the Theories}

Before discussing how aspects of cognitive theory and practice theory may be combined and applied to the study of the self in inscriptions, I will introduce briefly each theory and the aspects within them that I will combine. The theories have a similar approach in that they both emphasize the importance of context, but their points of focus and perceptions of the individual diverge. Each theory also gives a different perspective on the inscriptions and the selves created in them. With practice theory, the inscriptions are explained through the social practice they form a part of. Cognitive theory, however, explains the inscriptions from the starting point of the carver's cognitive process. The two theories are not as different as they seem, however, as cognition conditions every practice, and is also dependent upon the context in which it is situated.

5 These are only two of several possible approaches to the self, though I will not go into alternative approaches here. For a broader overview, see the introduction to this volume. 


\section{Cognitive Theory}

Within cognitive theory, I will focus on the concept of situated cognition, which defines cognition as interrelated with its context. According to proponents of situated cognition, cognitive processes are dependent upon the agent's body as well as the situation and context in which the cognitive process is located (see Robbins and Aydede 2009; Smith and Conrey 2009; Smith and Semin 2007). As an example, Smith and Conrey (2009) are concerned with how cognition is situated in a social context and how the communicative context, our relations to others, and associations with different social groups influence our cognitive processes. Moreover, they also discuss how, when in a group, people's thoughts evolve together as if all the group members together participate in a larger cognitive process. This is known as distributed cognition, and it has been demonstrated how the concept can explain complex teamwork and various other kinds of interaction between an agent and his or her surroundings. Examples are the use of a notebook to aid the memory (Clark and Chalmers 2010, 33-37), the various coordinated operations necessary for running a theatre performance in the Globe (Tribble 2005), the performance of a research project (Giere and Moffatt 2003: 305-8), and negotiation and formation of memory in a social group (Barnier et al. 2008; Lundhaug 2014). Distributed cognition offers interesting perspectives when discussing how inscriptions from the same context relate to each other, though it should be remarked that the concept is developed for describing simultaneous interaction and not interaction over time. The concept of distributed cognition can be perceived as an extreme version of situated cognition, where the surroundings not only affect the cognition; cognition is also extended to the surroundings.

Situated cognition can be explained through Gilles Fauconnier and Mark Turner's (1998) concept of blending (see also Eriksen and Turner, this volume). Fauconnier and Turner never use the term situated cognition, but blending nevertheless provides a neat explanation for this concept. When thinking about an idea, we expand it, and when we are finished thinking about this idea, we compress it again (Turner 2014, 23-24). But the idea we expand is not necessarily identical to the one we compress. We do not think in a vacuum, so elements from our surroundings sneak in, altering our old ideas or creating completely new ones as a blend between our old ideas and elements from our social and material surroundings (see Turner 2014, 24). Turning back to situated cognition, it can be explained as expansion and compression of ideas in different surroundings, where each new expansion and compression brings in new elements to the idea.

Our idea of who we are is such a blend that is continually expanded and compressed. According to Turner (2014, 77-78, 88), our sense of self is constructed 
dynamically and adapts to the circumstances we enter into. But at the same time, Turner writes, the "urge to compress and expand the self, to carry the self with us, seems to be a major influence on all our choices" $(2014,78)$. Our notion of a self, therefore, is not only dependent upon what experiences we have and what surroundings we are in, it is also the other way around. Our notion of a self also determines, at least to some degree, what choices we make and what situations and surroundings we seek out. The self is in our choices. Moving back to situated cognition, we see clearly the interdependent relationship between self and surroundings: the surroundings we are in, whether a grave mound, a cathedral, or an entirely different location, will determine how we perceive our self, but our notion of a self will determine what surroundings we choose to enter into.

\section{Practice Theory}

Practice theory is a cultural theory based on the fundamental assumption that practices are the basic structure of social life. I base my conception of practice theory on Theodore R. Schatzki (1996, 2001a, 2001b) and on the interpretation of Schatzki given by Andreas Reckwitz (2002a, 2002b, 2012) due to their emphasis of material surroundings, in addition to destabilizing factors such as affects, as components of the practice. Schatzki bases the theory on a reading of Ludwig Wittgenstein's works, which, he claims, help "position practices as the central phenomenon in the tangle that is human sociality" (Schatzki 1996, 12). Reckwitz, on the other hand, merges Theodore Schatzki's theory of social practices with Bruno Latour's emphasis on material objects as artifacts. Thus, in Reckwitz' account, a social practice is a doing or saying consisting of an agent (which is seen as a combination of body and mind), material objects, forms of knowing and understanding, and, finally, of routines and social structure; it is a routinized bodily and mental activity which builds on tacit knowledge and engagement with material objects and surroundings. In order to understand a practice, then, we need to take into account: material artifacts; the agent's body, mind, and tacit knowledge; and the social structures surrounding the practice. A feature distinguishing this version of practice theory from many other social theories is its focus on material artifacts as important components of the practice. Skis, for instance, are an important component of skiing, and the practice of skiing is just as meaningless without skis as without the human skier. Likewise, the practice of rune carving is impossible without anything to carve with and in. The material components of the practice are just as fundamental as the agents partaking in it. 
Schatzki (2001b, 12) sees the social as "a field of embodied, materially interwoven practices centrally organized around shared practical understandings.” In other words, practices are the fundamental feature of social life. Underlying the practices are "shared practical understandings." We may not be aware of these understandings; we may not even be able to explain them if we were asked. The understandings are embodied. According to Schatzki (2001b, 17), "the body is the meeting point both of mind and activity and of individual activity and social manifold.” As the understanding is rooted in our body, we know how to perform actions and comply with social norms without reflecting upon it. It is rooted in us. The embodied understanding and tacit knowledge we carry with us lead to reproduction of the practices; according to Reckwitz (2002b, 255), "[s]ocial practices are routines." In sum, then, practice theory explains how human beings interact with each other and their material surroundings, and how practices are learned and reproduced and thus create stability in a society.

When applying practice theory to an empirical material, a problem of definition arises: What exactly is a practice? How comprehensive is each practice, and how do they interrelate? Here, I will define a practice as a changing, yet relatively stable and repeating, pattern of actions. Thus, a carving practice is a repeating pattern of carving. The pattern repeats because the agents relate to earlier manifestations of the same pattern, and it changes according to the material and social surroundings and the agents partaking in the practice. For instance, a carving pattern repeats because new carvers relate to previous carvings. At the same time, a new material or social context, or new participants, may alter the pattern. Moreover, I understand practices as both overlapping networks and hierarchies. Thus, carving inscriptions in general may be termed an overarching practice (within the even broader practice of communication) wherein medieval graffiti carving is a sub-practice. This subpractice divides into ecclesiastical and non-ecclesiastical sub-practices, and again into local practices, which may in turn branch into yet another level of local subpractices which exist side by side in the same physical surroundings. I will refer to all of these levels as practices. Moreover, practices may interrelate across different categories: ecclesiastical and non-ecclesiastical inscriptions from the same area may, for instance, be closely related, and the same applies to formal inscriptions and graffiti found in the same church. Practices are not only organized hierarchically, therefore, but also as networks.

\section{Agency, Change, and Context as a Problem and Way Forward}

Two major problems for practice theory is how to explain individuality and change. Is our identity only the sum of the practices we partake in, or do we have a self 
independent of these? And can practices change? Reading introductions to practice theory (Reckwitz 2002b; Schatzki 2001b), it may seem like practice theoreticians do indeed view the individual as no more than the sum of the practices each person partakes in and that practices are static entities that cannot change. This would make practice theory an ill-suited theory both for the study of the self and for a tradition as multifaceted and changeable as graffiti carving. However, both Reckwitz and Schatzki introduce factors in their theoretical frameworks that allow for individuality and change. ${ }^{6}$ Reckwitz (2012) introduces what he terms affective spaces, stressing how the different components of a practice, particularly spaces, stir affects in the agents. Moreover, Reckwitz claims that spaces and affects have "destabilising and inventive potentials" (2012, 255). Schatzki (2001a) takes this a step further by introducing what he terms "teleoaffective structures," stating that mental states determine "what makes sense to people to do" (2001a, 57). Here, we arrive at a definition of practices as something much more than a simple repetition of actions by different agents. The agents are active participants, and their affects and ends are determining factors for how they choose to relate to the practice.

Cognitive theory fits neatly with the introduction to practice theory of affects and ends as both components seem to strengthen the cognitive aspects of the practice. Furthermore, cognitive theory holds as a fundamental assumption that human cognition is immensely flexible and in possession of agency (see Eriksen and Turner and Steen, this volume). Combining cognitive theory with a practice theory that incorporates affective spaces and teleoaffective structures leaves us with a framework where the agent acts within practices but still holds considerable agency. The agent is bound to relate to the practice, though how each agent chooses to relate to it is dependent on which other practices the agent partakes in, the affects with which the agent enters the practice, the affects the practice stirs in the agent, and the agent's intentions. The cognitive flexibility of the agent allows him or her to see multiple possibilities and choose between them. Often, the practice will dictate a specific course of action, and the agent will often choose this course, but that does not mean that $\mathrm{s} /$ he has not seen and considered other courses.

When merging cognitive and praxeological perspectives, the context for cognition also becomes much more well defined. As stated earlier, it is commonly acknowledged that our cognition is situated in a context, though many cognitivists only study a small fraction of this context. This is due to the fact that cognitive theory has experimental studies as an important part of its basis, and it is in the nature of such studies to focus on a certain aspect in a controlled

6 See also Raymond Caldwell's (2012) review of agency and change in Schatzki's work for another perspective on this. 
environment. When such studies are applied to real-life situations, however, there are innumerable other factors at play as well. Understanding the context of cognition through the lens of practice theory will provide a structure to these factors, as they are all understood as aspects of a practice. To situate cognition in a practice means that we always have to take into account the entire context for cognition, at least to the extent that we have access to it.

Returning to the concept of distributed cognition, we also see that there are similarities between this concept and practices. As noted earlier, the term distributed cognition has been used to describe complex forms of teamwork where the social aspects are central and where a common cognitive system is developed and distributed between the participants. Such systems are often described in a strikingly similar way to practices. Emily Tribble (2005, 140), for instance, puts strong emphasis on both the physical and social surroundings of the participants and states that the output of the cognitive processes is stored not only in each participant's mind, but also in the surroundings. In descriptions of distributed cognitive systems, cognition is presented as something more than mind. Cognition is, in short, extended to both social and material surroundings. Similarly, participants in a practice are both shaped by and shaping their physical and social context; the way the participants act both relies upon and affects their surroundings. Carving inscriptions, for instance, leaves physical traces in the surroundings, traces that in turn can shape how the practice is performed in the future.

The major difference between the two concepts seems to be that the term distributed cognitive system is primarily used to describe environments where the social interaction is immediate and where all participants have their designated and well-defined role. Not all practices fit this description, but they may nevertheless have elements of the distributed cognitive system in them. An advantage of understanding the two concepts as interrelated is that a cognitive understanding of practices may aid our understanding of each agent's participation and cognitive involvement with practices, while the praxeological assumption that all our actions are fundamentally learned through social interaction and organized in practices can add interesting perspectives to studies of distributed cognitive systems.

To return to the self: combining cognitive and praxeological perspectives may also give us a new approach to its definition. As a basis, I will use a cognitive definition of the self: I see the self as a cognitive idea of oneself that each person continuously constructs and reconstructs. ${ }^{7}$ As is stressed in the framework of situated cognition, though, this process of continuous construction never happens in a vacuum. It is situated in practices, and the agent's notion of

7 See Eriksen and Turner, this volume, for further discussions on this. 
self is heavily dependent upon the practice s/he partakes in. Moreover, I hold that a notion of self is also constructed within each practice and that each agent will relate to this self by cognitively blending it with his/her individual self. Thus, we have two concepts of self that overlap and interact: a communal sense of self created in the practice and an individually constructed self.

The self created in the practice is a social construction shared between all carvers partaking in the practice. From this perspective, the selves expressed in the inscriptions are, to a large extent, a product of shared tacit knowledge, and the self is reproduced in the inscriptions as part of the practice. This perspective leaves us with the self as it appears in the practice, rather than the self as it appears in the agent's cognition. Understanding the practice as a distributed cognitive system, however, we see that the self created in the practice is essentially a cognitively constructed self shared between and created by all the participants in the practice. When the agent engages cognitively with the practice, $s /$ he assigns the self in the practice to him-/herself. This self is a blend between the agent's sense of self before entering the practice and the self constructed within the practice. This cognitively constructed self is both communal - distributed across the participants in the practice - and individual. As every agent is different, they will all construct a sense of self in the practice that is individual to them and that may or may not differ from the other agents. Two agents in the same location can express a self that is much the same; this is ascribed to the fact that the agents' cognitive processes were situated in the same practice. Still, when partaking in the practice, the agent is free to add his or her own touch to the self $\mathrm{s} / \mathrm{he}$ expresses, blending the self of the practice with other layers of self. Each new agent will also add a new tinge of color to the self constructed in the practice, leaving parts of his/her self for new carvers to connect with.

Through participation in the practice, the carvers blend their self with the sense of self constructed in the practice, and this enables the agents to relate to and become part of the group. By repeating the practice and assigning the selves created there to themselves, new agents also express a sense of belonging to the group. Therefore, the communal self is inevitably a social self, although it may also have other aspects.

In conclusion, we have two concepts of the self, the communal, formed by outer practices, and the individual, formed by inner cognitive stimuli. When I move on to the selves we find expressed in graffiti inscriptions, I will see them as a mediation of the two: it contains aspects of the practice in which it is constructed, and thereby the communally constructed self, but it will also be colored by the carver's individual sense of self, the sense of self that the carver brings with him/her into the practice. The main benefit of bringing together practice theory and cognitive theory in the present article is that it allows for an 
understanding of the self expressed in inscriptions as a negotiation between the social practice and the carvers' individual cognition. By approaching two sets of inscriptions from different contexts with this understanding of the self, I will investigate how the interplay between practice and cognition is visible in the inscriptions. Furthermore, I will discuss how the selves expressed in the inscriptions are shaped by the carver's cognition and the practice of carving.

Before moving to the empirical discussions, however, it needs to be clarified that when discussing graffiti, the one prominent agent is the carver. In the following, I will therefore be referring to the carver's self, cognition, and practice, rather than the agent's.

\section{Medieval Graffiti}

The examples in this article will be taken from the corpora of runic inscriptions from Maeshowe (Fig. 1) and Nidaros Cathedral (Fig. 2). I do not give a general survey of the two corpora here, ${ }^{8}$ but for readers unfamiliar with the corpora, I present them briefly. Both corpora are varied and complex, and the selection of inscriptions presented here is not intended to give a full overview of them. ${ }^{9}$

Maeshowe is a Neolithic chambered cairn on Mainland, Orkney, where a group of Norse-speaking people broke in and filled the walls with runic inscriptions around the mid-twelfth century. Some of the inscriptions tie the carvers to a pilgrimage or crusade to Jerusalem, and it is believed that most, if not all, of the inscriptions were carved in the 1150s, when Orkneyinga saga tells of crusaders staying in Orkney. In other words, the inscriptions are likely to have been carved during a relatively short time, and most of the carvers probably knew each other. The Maeshowe corpus is unique in many respects. There are few corpora of runic inscriptions where we have this amount of contextual information, and, moreover, most of the inscriptions are very well preserved. In addition, this is by far

8 For general discussions on the corpora, see Barnes (1994) on Maeshowe and Norges innskrifter med de yngre runer (NIyR) vol. 5, Hagland (n.d.) and Syrett (2002) on Nidaros Cathedral. All inscription numbers are taken from these volumes: $\mathrm{N}+$ number refers to numbers in NIyR and Hagland (n.d.); Barnes/Syrett + numbers refer to numbers in Barnes (1994) and Syrett (2002), respectively. All transliterations and normalizations are based on these volumes; translations of inscriptions in Barnes (1994) are mainly based on that volume, while translations of the $\mathrm{N}$ inscriptions are done by me.

9 For more in-depth discussion on the selves expressed in these corpora, see Holmqvist (2019) for the inscriptions from Nidaros Cathedral and Holmqvist (forthcoming) for the Maeshowe inscriptions. 


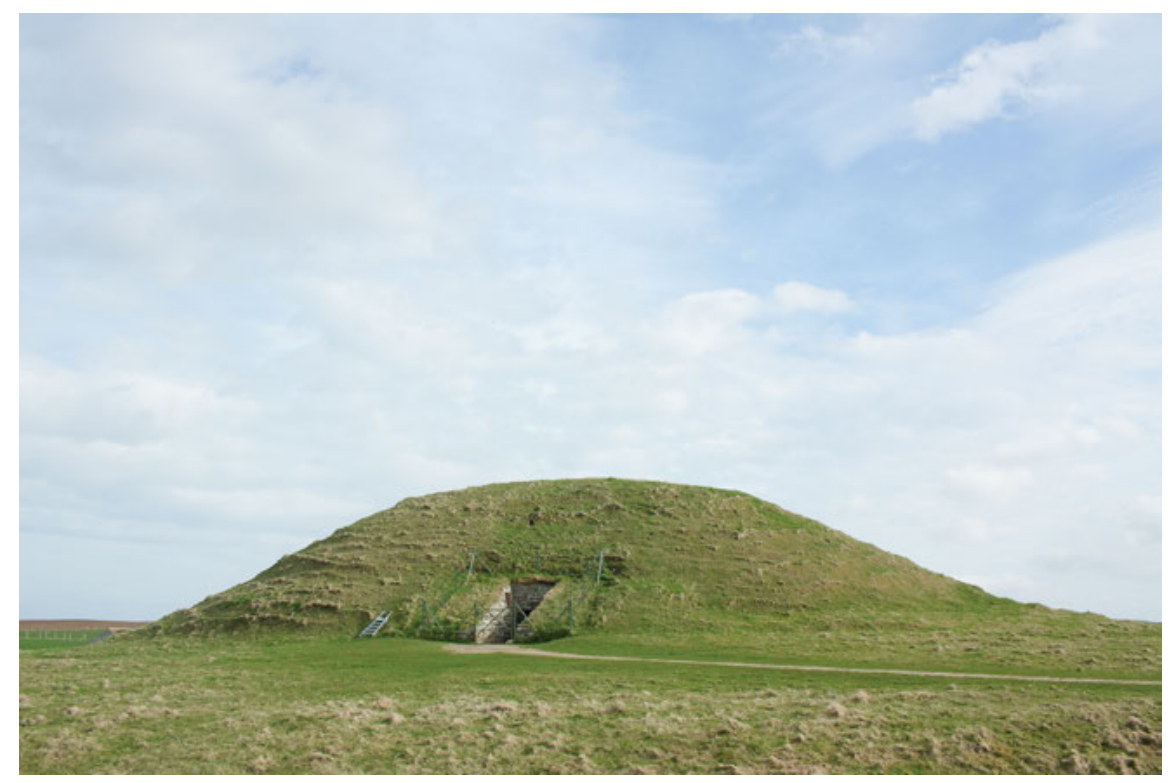

Fig. 1: Maeshowe is a Neolithic chambered cairn situated at Mainland, Orkney, which is filled with medieval runic graffiti. Photo by the author April 19, 2018.

the largest corpus of non-ecclesiastical runic graffiti. As such, it also gives us insight into a non-ecclesiastical medieval social setting.

The Nidaros Cathedral corpus, carved over a period of several hundred years, is not as unified as the Maeshowe corpus. It includes both runic and Roman alphabetic inscriptions that were carved over several hundred years. The oldest extant parts of the cathedral are from the twelfth century, and some inscriptions are likely to be almost as old as the walls they are carved on. The tradition of carving on the cathedral walls did not stop when the building process was completed, however; rather, it has continued to this day, making it difficult to separate the medieval from the post-medieval inscriptions.

In both corpora, we find several name inscriptions (i.e., inscriptions only consisting of one or more names) and agent inscriptions (typically following the formula ' $X$ carved'). Not surprisingly, though, there are more graffiti inscriptions of an explicitly religious character in the Nidaros Cathedral corpus. The carvers did not randomly carve anything anywhere; the practice changes when the material surroundings change, moving from a church to a chambered cairn without ecclesiastical connections. Participants in the church carving practice often choose explicitly religious messages (e.g., 'pray for me'), while, in Maeshowe, 




Fig. 2: Nidaros Cathedral is in Trondheim, Norway, and its walls are filled with both medieval and post-medieval graffiti inscriptions. Photo by the author October 15, 2016.

the carvers seem preoccupied with the mound itself and the treasures it might once have hidden. The Maeshowe carvers also carve inscriptions about sex and their own rune-carving skills. Both of these inscription types are known from other runic corpora as well (particularly the rune stick material), but they are less common in churches. Therefore, we see that while some types of graffiti (name and agent inscriptions) overlap and appear both in ecclesiastical and non-ecclesiastical environments, other types are either predominantly ecclesiastical or non-ecclesiastical.

\section{Analysis of the Inscriptions}

In accordance with the premises presented in the introduction, I treat graffiti carving as a practice in the following discussions. The practice, and thus also the contents and layout of the inscriptions, are determined by the physical surroundings (for instance, Maeshowe or a church), the available artifacts (such as 
a knife or another pointed object), the body and cognition of the carver, ${ }^{10}$ the routines that the carver has learned for carving runes, and the carver's tacit knowledge about and embodied understanding of inscriptions. Tacit knowledge, embodied understanding, and routines are picked up cognitively by the carvers when partaking in different practices. The bodily side of a practice may relate to movements, but also the physical possibilities and constraints provided by the carver's body. For instance, the carver's height will determine how high up s/he is able to carve. The carver also has an embodied understanding of how to move his/her body to carve the inscription. Cognitive activities include deciding what and where to carve. Such decisions are partly determined by the carver's tacit knowledge and by the routines he or she has learned. For instance, there are norms, manifest in the carver's tacit knowledge, for what to carve in different locations. Ultimately, though, the carver can choose how to relate to these norms and whether to follow them. Thus, the outcome of the carving process - the inscription itself and the self or selves it expresses - is a result of the mediation between the carver's cognition and the practice.

We can see the carvers in Maeshowe as active participants in a carving practice. It seems that the carvers knew each other and who had carved the inscriptions, ${ }^{11}$ a fact indicating that many of the inscriptions were carved during a relatively short period. Together, the carvers develop a practice by reading and commenting upon each other's inscriptions, developing a joint understanding of what to carve in this enclosed setting. This is apparent in inscriptions 23-32 in Maeshowe, where the carvers together create a narrative about the mound itself and a treasure supposedly hidden there (Fig. 3) ${ }^{12}$ :

10 Termed "body/mind" by Reckwitz (2002a; 2002b).

11 This is seen in inscription 8 in Maeshowe $(1994,93)$. . . . er mér sagt at fé er hér folgit órit vel. Segja fáir sem Oddr Orkasonr sagði á rúnum peim er hann reist. ' . . . [adverb?] is told to me that treasure is hidden here well enough. Few say as Oddr Orkasonr said in those runes which he carved.' In this inscription, the present carver refers to an inscription by Oddr Orkasonr. However, there is no inscription in Maeshowe signed with this name. This indicates that it was well known among the rune-carving community in Maeshowe who carved the inscriptions, including the unsigned ones.

12 The inscriptions are ordered in the suggested order of carving, see Barnes (1994, 171-4). Barnes claims that the final four inscriptions could have been carved either before or after the other six inscriptions, but I think it most likely that they were carved after. If these inscriptions were the first to be carved on the stone, this would be an odd place to choose; the upper half of the stone has a more comfortable height for carving, at least given that the carvers were adults. 


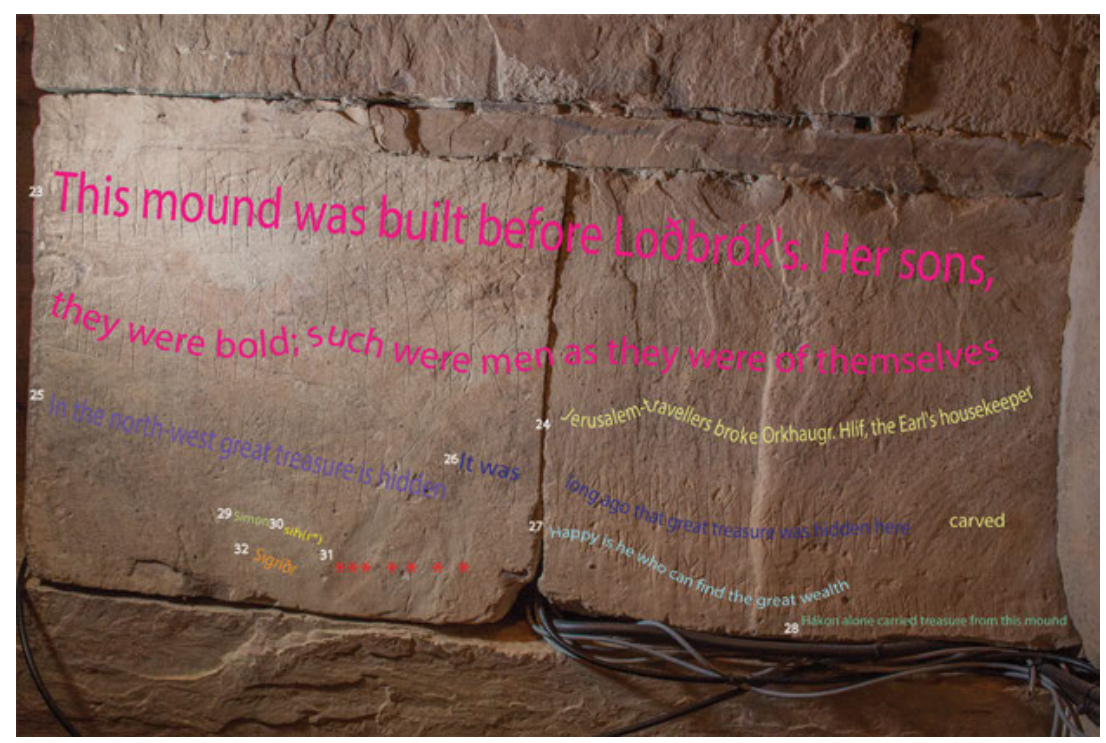

Fig. 3: Inscriptions nos. 23-32 in Maeshowe are located on two adjacent stones. In this figure, the translated inscription texts are given separate colors and are laid on top of their respective inscriptions to show how the inscriptions interact spatially and visually. The figure is made by the author.

\section{Barnes 23 sia $\cdot$ hquhr $\cdot$ uar $\cdot$ fyr $\cdot$ lapin: hæltr $\cdot$ lopbrokar $\cdot$ syner $\cdot$ hænar //} pæiruqro $\cdot$ huater $\cdot$ slituqro $\cdot$ mæn $\cdot$ sæmpæiruqrofyreser Sjá haugr var fyrr hlaðinn heldr Loðbrókar. Synir hennar, peir váru hvatir; slíkt váru menn, sem peir váru fyrir sér.

This mound was built before Loðbrók's. Her sons, they were bold; such were men, as they were of themselves [i.e., they were the sort of people you would really call men]. ${ }^{13}$

\section{Barnes 25 utnorbr: erfe $\cdot$ folhit $\cdot$ mikit}

Utnorðr er fé folgit mikit.

In the northwest great treasure is hidden.

\section{Barnes 28 • qkqnæinbarfeyrouhipisum}

Hákon einn bar fé ór haugi pessum.

Hákon alone carried treasure from this mound.

13 Bold typeface is a transliteration of the runes, italics give a normalization, and roman typeface gives the English translation. — indicates that two runes are written together, as a ligature, // indicates a line break, parentheses indicates uncertain runes, - indicates an unidentified rune, : and $\cdot$ indicate separation marks. 


\section{Barnes 27 sælersaerfinamapanquphinmikla}

Sæll er sá, er finna má pann auð hinn mikla.

Happy is he who can find the great wealth.

Barnes 26 • patuarlokoerheruarfefolhketmiket

pat var longu, er hér var fé folgit mikit.

It was long ago that great treasure was hidden here.

Barnes 24 iorsalafararbrutuorkquh · lifmtsæiliaiarls // ræist

Jórsalafarar brutu Orkhaug. Hlif, matselja jarls, reist.

Jerusalem-travelers [i.e., crusaders] broke Orkhaugr. Hlif, the Earl's housekeeper, carved.

Barnes 29 simon

Símon

Símon

Barnes 30 sih(r-)

(Sigríðr)

(Sigríðr)

Barnes 31 (----)

$\cdots$

$\cdots$

Barnes 32 sihrip

Sigríðr

Sigríðr

The ten inscriptions are found cramped together on two adjacent stones in Maeshowe, and their physical closeness to each other is the first indication that they relate to each other. Had one of the carvers not intended to relate his/her inscription to the other inscriptions, there would be several other locations in the mound where s/he would have had more space for carving. Furthermore, the carvers relate to each other thematically. We see how the first carver opens with a story about the supposed origins of the mound, tying it back to legendary times with the reference to Loðbrók. ${ }^{14}$ The second inscription seemingly starts a different topic about a treasure hidden in the northwest, while the third inscription ties the

14 It seems here that Loðbrók is a woman, but the (Ragnarr) Loðbrók known from the sagas is a man. Whether the two Loðbróks are the same is a different discussion (see Barnes 1994, 184 for a brief summary and references to further discussion), but what seems clear in this inscription is that the Loðbrók referred to here lived long ago and had a legendary status. 
first two together by suggesting that a treasure (the same?) was originally hidden in the mound. The two inscriptions following this one continue the treasure topic, while inscription no. 24 , the last of the long inscriptions, seems to go back to the topic of the mound. How Hlif, the carver of no. 24, relates to the other inscriptions is ambiguous. Does she suggest that their narrative is the wrong one and that the Jerusalem travelers rather than Hákon were the first to break into the mound? Or is she simply filling out the narrative about the mound? In any case, she is alone among the six carvers to sign her inscription, thus marking clearly her own contribution. This is by no means the only signed inscription in Maeshowe, but it stands out in this particular sub-practice, as the other five carvers seem more concerned with creating a joint narrative than with claiming their ownership to it.

In these inscriptions, we see how the carvers develop a practice. It is built on tacit knowledge of rune carving and of how to act in social and informal settings in general, while the carvers also feed the practice with new cognitive structures that subsequent carvers must adhere to if they want to participate. This can be understood as a distributed cognitive system that the carvers uphold and develop through their participation. Consequently, carvers determine what the practice is, and the practice determines what each carver will carve; each inscription is best understood when seen in relation to the others. The carver of no. 23, as the first of the ten inscriptions, establishes a practice for rune carving in this particular location. This practice is based on the carver's tacit knowledge of other rune carving practices, most prominent, perhaps, the rune carving practice found in the rest of Maeshowe. The other nine inscriptions repeat the practice established by the first carver, but with variations. The variation here is crucial, though, as it allows the carvers to express some individuality in how they relate to the topic. Note particularly inscription no. 27, which employs both rhymes and other poetic effects like a marked syntactic structure. The inscription does not add significant details to the narrative, though it adds fluency and a literary tone. The selves developed in this practice are implicit; by participating, the carvers state that they are interested in the topic of the inscriptions. They cognitively associate with a treasure-hunting and storytelling self through their participation. All the carvers might not have a personal interest in this, but to blend with this self is necessary to adhere to the practice and fit into the group. As such, one could also see the self developed in these inscriptions as a social self: through participation in the practice, the carvers establish themselves as members of the social group.

The final four inscriptions are single names or what appears to be attempts at carving names, and they could be completely unrelated to the rest of the group. However, given their placement, these inscriptions are most likely intended to be part of the same practice. There are indications that the carvers were less skilled in runes than their peers. This is seen in the shape of the runes 
in these four names, which are less neatly cut than the runes in most of the other inscriptions. Sometimes, it is also hard to identify which rune the carver intended to carve. Moreover, one of the names, that of Sigriðr, is seemingly carved twice, of which one is more successful than the other. If my conclusion is right, the carvers of these names may not have been skillful enough to participate fully in the discourse, but by carving their names, they could at least mark their participation in the practice; they could, for instance, have participated orally. As such, these four inscriptions can also be read as markers of group identity.

Looking at inscriptions from Nidaros Cathedral, we see again how the practice changes according to context. Here, the carvers' self-expressions are blended with the cathedral, as is seen in $\mathrm{N} 478$ :

\section{gup • ok : hin : hiælgi : olafr : kongr (:) hialpe (:) pæim (:) mane (:) er : pesar : runar : ræist : mepr : sinu : hæilahu : arnapar : orpe}

Guð ok hinn helgi Ólafr konungr hjalpi peim manni, er pessar rúnar reist með sínu heilagu árnaðarorði.

May God and the holy King Ólafr with their holy intercessions help the man who carved these runes.

The inscription was found on one of the outside walls of the octagon, ${ }^{15}$ inside of which the shrine of St. Ólafr was located. The carver probably addressed his inscription to St. Ólafr as this was his resting place, and he chose a location as close to the saint as possible. When choosing the cathedral as the place to carve his message, the carver tells us that he trusts in God and believes that his prayers are more likely to be heard if carved onto God's own house and close to St. Ólafr's resting place. As stated earlier, our self is in our choices; by approaching and carving here, the carver takes part in the carving practices of the cathedral, thus blending his sense of self with the atmosphere of the cathedral. Turner $(2014,77-78)$ writes that the self is adaptable, and this is seen here. The self most visible in this inscription is a self oriented towards God; it is a blend between the carver and the cathedral carving practice he partakes in. However, he must also have had other identities. We can presume, for instance, that if this carver had entered Maeshowe and chosen to participate in the carving practice, he would be likely to blend his self with the practices there and express a self more in line with the inscriptions there. Thus, the diversity in the material is likely to attest to the carvers' adaptability to different practices rather than to diversity in the interests of the carvers.

15 Though it is now on display at the museum in the Archbishop's Palace. 
Not all carvers in the cathedral display their religious identity as clearly as the one above. For instance, there are 15 clear and several uncertain examples of name inscriptions in the cathedral. Taken out of context, these could mean anything. Names appear in other contexts as well (e.g., on name tags and loose objects and in Maeshowe), and their meaning varies according to the practice they are carved in. I argue that the carvers, simply by partaking in the cathedral carving practice - which is ripe with other more explicitly religious inscriptions - express a religious identity. In the cathedral, the carver's self will be blended with the ecclesiastical environment. Moreover, when reading and interpreting an inscription in a cathedral, the reader is likely to interpret the inscription in light of its location and read it as part of the cathedral carving practice, thus creating a blend between the inscription and the other activities taking place in the cathedral. There are two examples from Nidaros Cathedral that imply that this is how at least some readers interpreted the inscriptions. These are N 493 (Fig. 4) and N 494, both found on the inside walls of the octagon. Here, there were originally two single names: Ketill and Erlingr, and later, both were expanded to prayers ${ }^{16}$ :

\section{(k)uptakisalketillss}

Guð taki sál Ketils.

May God take Ketill's soul.

\section{kupkætipinærlingrsikmuntarsonnuokiafnân}

Guð gæti pín, Erlingr Sigmundarsonr, nú ok jafnan.

May God protect you, Erlingr Sigmundr's son, now and forever.

Thus, we see here how two readers have interpreted the name inscriptions within the cathedral practice as requests for prayers and have decided to answer these requests by carving prayers for the names. ${ }^{17}$ This also testifies to how people can interact through the inscriptions. Just like in Maeshowe, carving is a social phenomenon. By partaking in a church carving practice, the carver is not only blending his/her self with the cathedral, but also with the community of people belonging there. This argument can be extended to most of the inscriptions in the cathedral, though there are a few inscriptions that seemingly deviate completely from the practice, and thus where this argument

16 See NIyR, 5:56-57 for arguments why these inscriptions must have been carved in two stages.

17 See Holmqvist (2019) for further discussion of these inscriptions. 


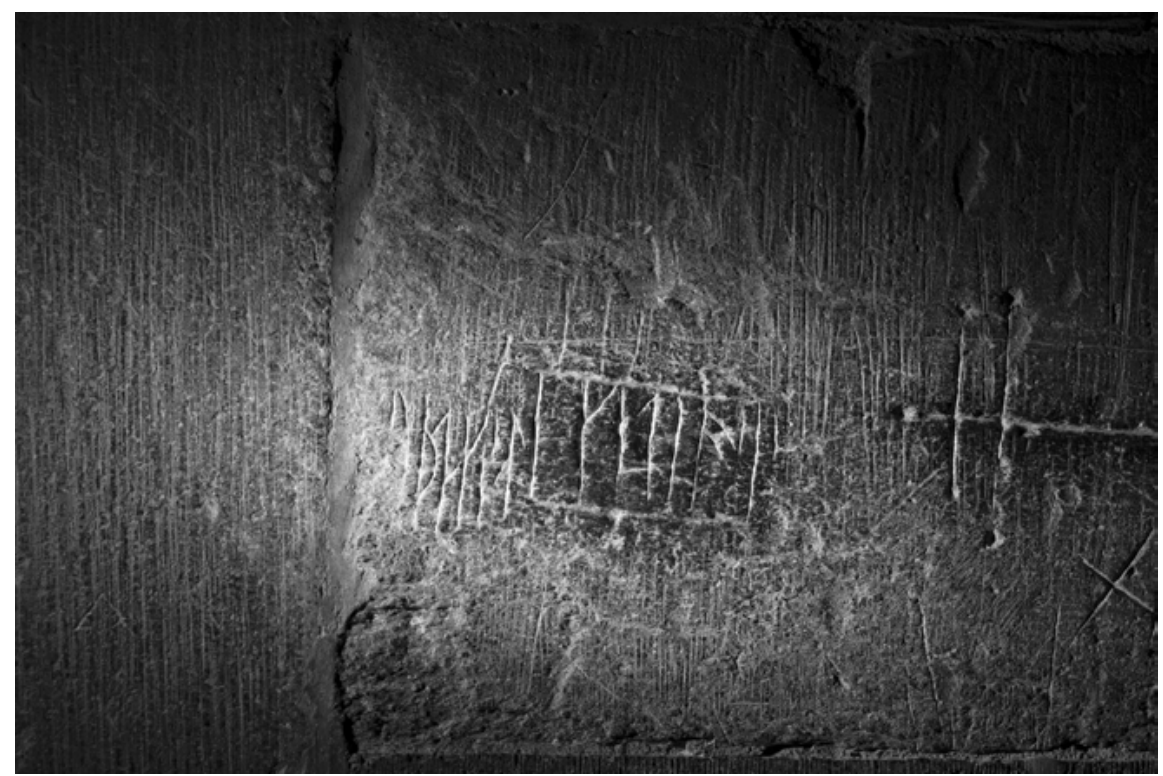

Fig. 4: "Guð taki sál Ketils." (May God take Ketill’s soul.) The inscription was carved in two stages. First, Ketill's name was carved and given a frame. Later, someone added a prayer to the name. Photo by the author November 28, 2017.

is not valid. Here, the carvers cannot be said to express a religious or social self through their inscriptions. ${ }^{18}$

In the examples above, we see how the carvers relate cognitively both to their physical surroundings, i.e., the cathedral or the mound and other inscriptions found in the vicinity, and enter into a dialogue with these surroundings through the inscriptions s/he carves. Through the inscriptions, carvers cognitively associate or dissociate themselves with the practices surrounding them, thus defining themselves as either inside or outside of the group. Moreover, the practices also influence what other selves the carvers choose to express. For instance, many carvers in the cathedral explicitly express a religious self. This will define them as part of the group as they conform to the norms for church inscriptions. However, the fact that carvers choose to carve in a church at all tells us that they saw themselves as persons devoted to God or the Church. There are seemingly no similar connotations connected to Maeshowe, so here, the practice is also more open and flexible,

18 An example is Syrett 9, a slanderous inscription insinuating that one of the church authorities was gay. 
but it is nevertheless clear that norms were established through the practices that the carvers developed, and that most carvers chose to follow these norms. Thus, we see a social self emerging, although a social self choosing actively to be social by cognitively associating itself with the group.

\section{Conclusion}

In conclusion, I will turn back to the two research questions presented initially:

1) How is the interplay between practice and cognition visible in the inscriptions?

2) How are the selves expressed in the inscriptions shaped by the carvers' cognition and the practice of carving?

The questions meet in the two concepts of self presented above: the communally constructed self created in the practice and the individually constructed self created in each carver's cognition. The two are interrelated and will color each other, but we still see traces of both in the inscriptions cited in the discussions. In Maeshowe, we see how the practice requires the construction of a narrative, though the way in which the carvers contribute to this narrative is highly individual. While one adds a dreamy and poetic inscription about finding the treasure, others provide flesh to the story by stating facts like who took the treasure and where it is hidden. Likewise, in Nidaros Cathedral, many inscriptions relate to the ecclesiastical setting in which they were carved, while their approach to this setting varies greatly. In the cited inscriptions, we find carvers carving their name, carvers requesting intercession for themselves, and carvers praying for others. Looking at the entire cathedral material, one would discover even more diversity, including inscriptions which seemingly deviate from the predominant practice. Even so, the cathedral context invites less diversity than Maeshowe, indicating that although both contexts allow for diversity in expression and some degree of cognitive exploration, the carving practices in the cathedral seem to be more restrictive. Thus, the selves expressed in the Maeshowe inscriptions are also more diverse, allowing greater room for the individually constructed selves. In the end, what each carver chooses to carve is probably dependent upon the situation s/he was in at the moment of carving. A young woman eager to be accepted by her peers, a father grieving the loss of his son, and a carver desperate for forgiveness for the sin she once committed would be likely to carve very different inscriptions. Although the carvers very rarely tell us about such circumstances, we should assume that some of the variation we see can be ascribed to the carvers' personal situations. 
In this article, I have shown how medieval graffiti can be understood as the result of a cognitive process situated in a practice, resulting in the insight that inscriptions are always created in a mediation between the carver's cognition and the practice in which the carver is situated. Social requirements are weighted against the carvers' wishes to express themselves, though in some contexts, the social requirements are more restrictive and regulating than in others. This perspective can be useful when studying several aspects of the carving process and the situation in which the inscriptions were carved, but here I have focused on what the perspective can contribute when studying the self. The combination of cognitive theory and practice theory shows us how the self is both social and personal - created both cognitively and in the practice, and always in a relation to other selves.

Acknowledgements: I am indebted to participants at the research school Authoritative Texts and Their Reception's fall seminar in 2018, my supervisors Stefka G. Eriksen, Karl G. Johansson, and Kristel Zilmer, the editors and the anonymous reviewers who have read the manuscript for this article at various stages in the writing process. Their comments have helped me develop and convey more clearly the ideas expressed in this article.

\section{References}

\section{Primary Sources}

Barnes, Michael P. 1994. The Runic Inscriptions of Maeshowe, Orkney. Runrön, 8. Uppsala. Hagland, Jan Ragnar. n.d. "Runer frå utgravingane i Trondheim bygrunn 1971-94. Med eit tillegg av nyfunne innskrifter elles frå byen (N774-N894):" https://www.arild-hauge. com/PDF/Runer\%20fra\%20utgravingane\%20i\%20Trondheim\%20bygrunn\%201971-94. pdf (accessed March 27, 2020).

NlyR = Norges innskrifter med de yngre runer. 1941-. Ed. Magnus Olsen, Aslak Liestøl, Ingrid Sanness Johnsen, and James Knirk. 6 vols. Oslo.

Orkneyinga saga. 1965. In Orkneyinga saga. Ed. Finnbogi Guðmundsson. Íslenzk fornrit, 34. Reykjavík. 1-300.

Syrett, Martin. 2002. The Roman-Alphabet Inscriptions of Medieval Trondheim, I. Trondheim.

\section{Secondary Sources}

Barnes, Michael P. 2013. “What Is Runology, and Where Does It Stand Today?" Futhark: International Journal of Runic Studies 4: 7-30. 
Barnier, Amanda J., John Sutton, Celia B. Harris, and Robert A. Wilson. 2008. "A Conceptual and Empirical Framework for the Social Distribution of Cognition: The Case of Memory." Cognitive Systems Research 9.1: 33-51.

Bauer, Alessia, Elise Kleivane, and Terje Spurkland, eds. 2018. Epigraphy in an Intermedial Context. Dublin.

Bianchi, Marco. 2010. Runor som resurs. Vikingtida skriftkultur i Uppland och Södermanland. Runrön, 20. Uppsala.

Caldwell, Raymond. 2012. "Reclaiming Agency, Recovering Change? An Exploration of the Practice Theory of Theodore Schatzki." Journal for the Theory of Social Behaviour 42.3: 283-303.

Clark, Andy and David J. Chalmers. 2010. "The Extended Mind.” In The Extended Mind. Ed. Richard Menary. Cambridge, MA. 7-19.

Fauconnier, Gilles and Mark Turner. 1998. “Conceptual Integration Networks.” Cognitive Science 22.2: 133-87.

Giere, Ronald N. and Barton Moffatt. 2003. "Distributed Cognition: Where the Cognitive and the Social Merge." Social Studies of Science 33.2: 301-10.

Holmqvist, Karen Langsholt. 2019. "Names and Prayers: Expressions of Self in the Medieval Inscriptions of the Nidaros Cathedral Walls." Collegium Medievale 31 (2018): 103-49.

Holmqvist, Karen Langsholt. Forthcoming 2020. “mihgil oflate 'A Great Show-off': The Selves in the Runic Inscriptions of Maeshowe, Orkney." Viking and Medieval Scandinavia 16.

Jesch, Judith. 1994. "Runic Inscriptions and Social History: Some Problems of Method." In Proceedings of the Third International Symposium on Runes and Runic Inscriptions. Grindaheim, Norway, 8-12 August 1990. Ed. James E. Knirk. Runrön, 9. Uppsala. 150-62.

Lundhaug, Hugo. 2014. "Memory and Early Monastic Literary Practices: A Cognitive Perspective." Journal of Cognitive Historiography 1.1: 98-120.

Nielsen, Michael Lerche. 1997. "Runologien mellem sprogvidenskaben og arkæologien - med et sideblik på de forskellige tolkninger af Glavendrupindskriften.” In Sekstende tværfaglige vikingesymposium. Ed. Hans Bekker-Nielsen and Hans Frede Nielsen. Odense Universitet. 37-51.

Peterson, Lena. 1995. "Runologi. Försök till ett aktuellt signalement." Saga och sed. Kungl. Gustav Adolfs akademiens årsbok 1995: 39-54.

Reckwitz, Andreas. 2002a. "The Status of the 'Material' in Theories of Culture: From 'Social Structure' to 'Artefacts'." Journal for the Theory of Social Behaviour 32.2: 195-217.

Reckwitz, Andreas. 2002b. "Towards a Theory of Social Practices: A Development in Culturalist Theorizing." European Journal of Social Theory 5.2: 243-63.

Reckwitz, Andreas. 2012. "Affective Spaces: A Praxeological Outlook." Rethinking History: The Journal of Theory and Practice 16.2: 241-58.

Robbins, Philip and Murat Aydede. 2009. "A Short Primer on Situated Cognition.” In The Cambridge Handbook of Situated Cognition. Ed. Philip Robbins and Murat Aydede. New York. 3-10.

Schatzki, Theodore R. 1996. Social Practices. A Wittgensteinian Approach to Human Activity and the Social. Cambridge.

Schatzki, Theodore R. 2001a. “3. Practice Mind-ed Orders." In The Practice Turn in Contemporary Theory. Ed. Theodore R. Schatzki, Karin Knorr Cetina, and Eike von Savigny. New York. 50-63. 
Schatzki, Theodore R. 2001b. "Introduction: Practice Theory." In The Practice Turn in Contemporary Theory. Ed. Theodore R. Schatzki, Karin Knorr Cetina, and Eike von Savigny. New York. 10-23.

Smith, Eliot R. and Frederica R. Conrey. 2009. "The Social Context of Cognition.” In The Cambridge Handbook of Situated Cognition. Ed. Philip Robbins and Murat Aydede. New York. 454-66.

Smith, Eliot R. and Gün R. Semin. 2007. "Situated Social Cognition.” Current Directions in Psychological Science 16.3: 132-35.

Spurkland, Terje. 1987. “Runologi - arkeologi, historie eller språkvitenskap?” Norskrift: Tidsskrift for nordisk språk og litteratur 52: 46-58.

Tribble, Evelyn. 2005. “Distributing Cognition in the Globe.” Shakespeare Quarterly 56.2: 135-55.

Turner, Mark. 2014. The Origin of Ideas: Blending, Creativity and the Human Spark. New York. Williams, Henrik. 2013. "Runstenarnas sociala dimension." Futhark: International Journal of Runic Studies 4: 61-76. 
